\title{
Study on Relationship between Profile Characteristics of Groundnut Farmers and their Marketing Behaviour in Anantapuramu District of Andhra Pradesh, India
}

\author{
A. Vineetha ${ }^{1 *}$, V. Sailaja ${ }^{1}$ and P.V. Satya Gopal ${ }^{2}$ \\ ${ }^{1}$ Department of Agricultural Extension, S.V Agricultural College, Tirupati, India \\ ${ }^{2}$ Department of Agricultural Extension, Agricultural College, Bapatla, India \\ *Corresponding author
}

\section{A B S T R A C T}

\begin{tabular}{|l|}
\hline Ke y w o r d s \\
Groundnut farmers, \\
Profile \\
characterisics, \\
Marketing \\
behaviour, \\
Education, \\
Correlation \\
\hline Article Info \\
\hline Accepted: \\
04 March 2019 \\
Available Online: \\
10 April 2019 \\
\hline
\end{tabular}

Study on relationship between profile characteristics of groundnut farmers and their marketing behaviour aimed to bring out a strategy to increase the marketing behaviour of groundnut farmers. The Present investigation was carried out in Anantapuramu district of Andhra Pradesh. The results of the study revealed that the independent variables viz., Education, Annual income, Material possession, Extension contact, Trainings received and Social participation were found to be positively significant with the marketing behaviour of the groundnut farmers and age, area under groundnut cultivation, experience in groundnut cultivation and agricultural inputs acquisition pattern were found negatively significant with the marketing behaviour of the groundnut farmers. All the selected 10 independent variables put together explained about 76.00 per cent variation in the marketing behaviour of groundnut farmers.

\section{Introduction}

Groundnut is a major oilseed crop that has achieved tremendous popularity in the country. It is called as the king of oilseeds. It is one of the most important food and cash crop of our country. While being a valuable source of all the nutrients, it is low priced commodity. India is the world's leading producer of groundnut with 25.00 per cent share in the production. In Andhra Pradesh, the area covered under oilseeds was 12.29 lakh hectares covering $16.57 \%$ of the total cropped area, while the groundnut crop alone covered an area of $82.39 \%$ of the total area under oil seeds. Anantapuramu is the predominant groundnut cultivated district in the state with an extent of 624000 hectares with the production of 164000 tons. The groundnut farmers are at a disadvantage particularly in the marketing of groundnut as they lose their bargaining strength and got exploited. Monthly data on minimum prices of groundnut in Anantapuramu regulated 
market yard show a highly erratic behaviour. Such kind of fluctuations in the prices of groundnut reflects on the poor withholding capacity of the marginal and small farmers while marketing their final produce. The present research paper focuses on the relationship between profile characteristics of groundnut farmers and their marketing behaviour actually studied in the main research study.

\section{Materials and Methods}

Anantapuramu district of Andhra Pradesh was purposively selected as groundnut was being extensively cultivated in the district. Out of 63 mandals of Anantapuramu district, three mandals were purposively selected based on the highest area under groundnut cultivation. Four villages from each mandal were selected based on highest area under groundnut cultivation, thus making a total of twelve villages for the study. From each of the twelve selected villages, 10 respondents were selected by following simple random sampling procedure, thus making a total of 120 respondents. The data were collected by personal interview method through structured interview schedule and analyzed by employing suitable statistical tools like Arithmetic mean, Standard deviation, Frequencies and percentages were used. The simple correlation coefficient was used to find out the correlation between the independent variables and marketing behaviour to know the degree of association between the variables. Multiple regression analysis was also carried out to find out functional relationship between independent variables and marketing behavior

\section{Results and Discussion}

In order to study the relationship between the profile characteristics and the marketing behaviour of groundnut farmers, correlation coefficient (r) were computed and the values are presented in Table 1.

\section{Age Vs marketing behaviour}

From the Table 1 it is evident that co-efficient of correlation $(r=0.104)$ between age and marketing behaviour of groundnut farmers was less than the table value of ' $r$ ' at 0.05 level of significance. Therefore, it could be inferred that there was a positive and nonsignificant relationship between age and marketing behaviour of the groundnut farmers.

The results indicated that variation in marketing behaviour had no influence on the age of the respondents. The possible reason might be due to the fact that irrespective of age of the respondent, the marketing behaviour of groundnut farmers was dependent on individual's personal interest and educational level.

\section{Education Vs marketing behaviour}

From the Table 1 it is evident that co-efficient of correlation $(r=0.193)$ between education and marketing behaviour of groundnut farmers was greater than the table value of ' $r$ ' at 0.05 level of significance. Therefore, it could be inferred that there was a positive and significant relationship between education and marketing behaviour of the groundnut farmers.

The probable reason for this educated farmers with more information seeking habits had better access to information sources such as farm magazines, books and also more exposure to extension agencies, scientists and research stations, which also contribute to their increased knowledge in all aspects particularly in the area of marketing which results in increased marketing behaviour. 
Area under groundnut cultivation Vs marketing behaviour

From the Table 1, it is evident that coefficient of correlation $(\mathrm{r}=0.136)$ between area under groundnut cultivation and marketing behaviour of groundnut farmers was less than the table value of ' $r$ ' at 0.05 level of significance. Therefore, it could be inferred that there was a positive and nonsignificant relationship between area under groundnut cultivation and marketing behaviour of the groundnut farmers. The above results indicated that variation in marketing behaviour had no influence on the area under groundnut cultivation of the respondents. The probable reason might be that irrespective of their area under groundnut cultivation the farmers possessed knowledge about marketing aspects because of their educational level and interpersonal contacts with friends, neighbors, extension agencies and others.

\section{Experience in groundnut cultivation Vs marketing behaviour}

From the Table 1, it is evident that coefficient of correlation $(r=0.096)$ between experience in groundnut cultivation and marketing behaviour of groundnut farmers was less than the table value of ' $r$ ' at 0.05 level of significance.. Therefore, it could be inferred that there was a positive and nonsignificant relationship between experience in groundnut cultivation and marketing behaviour of the groundnut farmers. The probable reason might be that irrespective of their farming experience in groundnut cultivation, farmers gain more knowledge about marketing in groundnut through their educational level and personal interest.

\section{Annual income Vs marketing behaviour}

From the Table 1, it is evident that coefficient of correlation $(\mathrm{r}=0.483)$ between annual income and marketing behaviour of groundnut farmers was greater than the table value of ' $r$ ' at 0.01 level of significance. Therefore, it could be inferred that there was a positive and significant relationship between annual income and marketing behaviour of the groundnut farmers. The probable reason might be that high annual income makes a farmer to strive to get more information to meet his marketing requirements and the resource rich farmers who belonged to high income group might have exerted feeling to try to follow new technology towards profits as well as security maximization. Hence, farmers came to know different marketing channels.

\section{Material possession Vs marketing behaviour}

From the Table 1, it is evident that coefficient of correlation $(r=0.586)$ between material possession and marketing behaviour of groundnut farmers was greater than the table value of ' $r$ ' at 0.01 level of significance. Therefore, it could be inferred that there was a positive and significant relationship between material possession and marketing behaviour of the groundnut farmers. The probable reason might be that increase in annual income will increase the material possession of the farmers. Normally a farmer with high annual income, high level of material possession will look forward convenient and sophisticated transport mechanism to carry the farm produce from production center to the far off sale points to get remunerative prices.

\section{Extension contact Vs marketing behaviour}

From the Table 1, it is evident that coefficient of correlation $(r=0.809)$ between extension contact and marketing behaviour of groundnut farmers was greater than the table value of ' $r$ ' at 0.01 level of significance. 
Therefore, it could be inferred that there was a positive and significant relationship between extension contact and marketing behaviour of the groundnut farmers. The probable reason might be that regular contacts with various extension agencies could enable the farmers to access to the valid, reliable and accurate market related information. Higher the extension contact greater the scope of getting information about marketing aspects.

\section{Trainings received Vs Marketing behaviour}

From the Table 1, it is evident that coefficient of correlation $(\mathrm{r}=0.226)$ between trainings received and marketing behaviour of groundnut farmers was greater than the table value of ' $r$ ' at 0.05 level of significance. Therefore, it could be inferred that there was a positive and significant relationship between trainings received and marketing behaviour of the groundnut farmers. The possible reason for this might be that farmers who have undergone trainings were knowing the importance of marketing and they wanted to get more information about different markets and prices prevailing in different markets for the groundnut produce.

\section{Agricultural inputs acquisition pattern Vs Marketing behaviour}

From Table 1, it is evident that co-efficient of correlation $(\mathrm{r}=0.126)$ between agricultural inputs acquisition pattern and marketing behaviour of groundnut farmers was less than the table value of ' $r$ ' at 0.05 level of significance. Therefore, it could be inferred that there was a positive and non-significant relationship between agricultural inputs acquisition pattern and marketing behaviour of the groundnut farmers. The reason might be that most of the farmers procured agricultural and financial inputs from money lenders and intermediaries which resulted in less exposure to other financial and nonfinancial organizations which are helping the farmers directly or indirectly to get information about various market related aspects.

Table.1 Correlation coefficients between the selected profile characteristics with the marketing behaviour of groundnut farmers

\begin{tabular}{|c|c|c|c|}
\hline S. No. & $\begin{array}{c}\text { Variable } \\
\text { No. }\end{array}$ & Independent variable & $\begin{array}{c}\text { Correlation } \\
\text { coefficient (r) } \\
\text { values }\end{array}$ \\
\hline 1 & $\mathrm{X}_{1}$ & Age & $0.104^{\mathrm{NS}}$ \\
\hline 2 & $\mathrm{X}_{2}$ & Education & $0.193^{*}$ \\
\hline 3 & $\mathrm{X}_{3}$ & Area under groundnut cultivation & $0.136^{\mathrm{NS}}$ \\
\hline 4 & $\mathrm{X}_{4}$ & Experience in groundnut cultivation & $0.096^{\mathrm{NS}}$ \\
\hline 5 & $\mathrm{X}_{5}$ & Annual income & $0.483^{* *}$ \\
\hline 6 & $\mathrm{X}_{6}$ & Material possession & $0.586^{* *}$ \\
\hline 7 & $\mathrm{X}_{7}$ & Extension contact & $0.809^{* *}$ \\
\hline 8 & $\mathrm{X}_{8}$ & Trainings received & $0.226^{*}$ \\
\hline 9 & $\mathrm{X}_{9}$ & Agricultural inputs acquisition pattern & $0.126^{\mathrm{NS}}$ \\
\hline 10 & $\mathrm{X}_{10}$ & Social participation & $0.246^{* *}$ \\
\hline
\end{tabular}


Table.2 Multiple Linear Regression analysis of the selected independent variables with the marketing behaviour of groundnut farmers

\begin{tabular}{|c|c|c|c|c|c|}
\hline \multirow{2}{*}{$\begin{array}{l}\text { S. } \\
\text { No. }\end{array}$} & \multirow[t]{2}{*}{ Variable } & \multicolumn{4}{|c|}{ Groundnut farmers $(n=120)$} \\
\hline & & $\begin{array}{l}\text { Sta. } \\
\text { error }\end{array}$ & 'b' values & 't'values & 'P' values \\
\hline $\mathbf{X}_{1}$ & Age & 0.91 & 0.97 & 0.712 & 0.478 \\
\hline $\mathbf{X}_{2}$ & Education & 0.237 & 0.84 & 1.683 & 0.095 \\
\hline $\mathbf{X}_{\mathbf{3}}$ & Area under groundnut cultivation & 0.506 & -0.089 & -1.667 & 0.098 \\
\hline $\mathbf{X}_{4}$ & $\begin{array}{l}\text { Experience in groundnut } \\
\text { cultivation }\end{array}$ & 0.113 & -0.046 & -0.331 & 0.742 \\
\hline $\mathbf{X}_{5}$ & Annual income & 0.012 & 0.202 & $3.594 * *$ & 0.000 \\
\hline $\mathbf{X}_{6}$ & Material possession & 0.263 & 0.225 & $3.929 * *$ & 0.000 \\
\hline $\mathbf{X}_{7}$ & Extension contact & 0.199 & 0.648 & $11.31 * *$ & 0.000 \\
\hline $\mathbf{X}_{8}$ & Training received & 0.529 & 0.021 & 0.420 & 0.675 \\
\hline $\mathbf{X}_{9}$ & $\begin{array}{l}\text { Agricultural inputs acquisition } \\
\text { pattern }\end{array}$ & 0.298 & -0.057 & -1.133 & 0.260 \\
\hline $\mathbf{X}_{10}$ & Social participation & 0.183 & -0.005 & -0.096 & 0.924 \\
\hline $\begin{array}{ll}* & : \\
* * & : \\
N S & \end{array}$ & $\begin{array}{l}\text { Significant at } 5 \% \text { level of probability } \mathrm{R}^{2}= \\
\text { Significant at } 1 \% \text { level of probability } \\
: \quad \text { Non-significant }\end{array}$ & & & & \\
\hline
\end{tabular}

\section{Social participation Vs marketing} behaviour

From the Table 1, it is evident that coefficient of correlation $(r=0.246)$ between social participation and marketing behaviour of groundnut farmers was greater than the table value of ' $r$ ' at 0.01 level of significance. Therefore, it could be inferred that there was a positive and significant relationship between social participation and marketing behaviour of the groundnut farmers. The possible reason might be that increased social participation of farmers provides more chances of getting exposed to different sources and ideas related to marketing.

The ' $\mathrm{R}$ ', value of 0.760 which depicted that all the selected ten independent variables put together explained about 76.00 per cent variation in the marketing behaviour of groundnut farmers. The multiple regression coefficients presented in Table 2 further revealed that the independent variables viz.,
Annual income, Material possession and Extension contact were found positively significant as evident from their significant ${ }^{\prime} t$ ' values. This implied that Annual income, Material possession and Extension contact have contributed to most of the variation in the marketing behaviour of groundnut farmers. Normally a farmer with high annual income makes him to strive hard to get more information through various means to meet his marketing requirements. High level of material possession will look forward the convenient and sophisticated transport mechanism to carry the farm produce from production center to the far off sale points to get remunerative prices. Higher the extension contact greater the scope of getting information about marketing aspects.

So concluded that the independent variables Education, Annual income, Material possession, Extension contact, Trainings received and Social participation were found to be positively significant with the marketing 
behaviour of the groundnut farmers and age, area under groundnut cultivation, experience in groundnut cultivation and agricultural inputs acquisition pattern were found negatively significant with the marketing behaviour of the groundnut farmers. Annual income, Material possession and Extension contact have contributed to most of the variation in the marketing behaviour of groundnut farmers. All the selected 10 independent variables put together explained about 76.00 per cent variation in the marketing behaviour of groundnut farmers.

\section{References}

Desai, J.D and Solanki, K.D .2013. Extent of adoption of market intelligence among the summer cabbage growers of Sardar Krushinagar district in Gujarat. Gujrat Journal of Extension Education. 24: 9-13

Dhara, R., Umamageswari, $\mathrm{M}$ and
Porchezian, S.2015. Characteristics and marketing behaviour of coconut growers in Thanjavur district of Tamilnadu. International Research Journal of Agricultural Economics and Statistics. ISSN-2231-6434.

Hameed, T.S and Sawicka, B. 2017. Production and Marketing problems of Potato growers, International Journal of Current Research. 9, 0(5), 4972949732.

Jaisridhar, P., Ravichandran, V., Jadoun Y.S and Senthil Kumar, R. 2012. Study on adoption and marketing behaviour of maize growers in Coimbatore district of Tamil Nadu. Indian Journal of Agricultural Research. 46(2):173-177.

Johnson and Manoharan, M. 2009. Marketing behaviour of Cashew farmers. Indian Research Journal of Extension Education 9(1).

\section{How to cite this article:}

Vineetha, A., V. Sailaja and Satya Gopal, P.V. 2019. Study on Relationship between Profile Characteristics of Groundnut Farmers and their Marketing Behaviour in Anantapuramu District of Andhra Pradesh, India. Int.J.Curr.Microbiol.App.Sci. 8(04): 253-258. doi: https://doi.org/10.20546/ijcmas.2019.804.027 